Reprinted with permission from $R D$ Management 17:167-73, 1987. Copyright 1987 Basil Giackweit.

\title{
Firm and industry characteristics influencing publications of scientists in large American companies
}

\author{
Michael R. Halperin \\ Lippincott Library, University of Pennsylvania, PA 19104, USA \\ and \\ Alok K. Chakrabarti \\ Drexel University, Philadelphia PA 19104 and \\ Institut fur Betriebswirtschaftslehre, University of Kiel
}

Back to Introduction

Abstract

This study examines the relationship between the volume itive response (Mansfield 1986 has elaborated on this issue with detailed empirical evidence).

Sociological studies have used publications (sciof scientific and technical publications (papers) produced by incustrial scientists, and the characteristics of the corporations in which they work. Specifically, the study examines 1 . the relationship between several key financial characteristics of U.S. industrial firms and the production of scientific papers; 2 . the relationship between the amount of scientific papers published by industrial scientists and the publication of patents; 3 . the relationship between the quality of the scientists employed by U.S. industrial firms and the firms' output of papers and patents. Data from 225 U.S. corporations were collected for the years 1975 through 1983. The corporations chosen for the study all have a history of consistent R\&D expenditure. There is a substantial correlation between patenting and the publication of scientific papers although controlling for the size of the corporation reduces the correlation. Lasge firms, as measured by their annual sales, produce proportionately fewer scientific papers than do small firms. The number of elite scientists in a corporation is more highly correlated with the publication of scientific papers than with patenting.

\section{INTRODUCTION}

In studies of industrial innovation, patents and publications have been used as surrogate measures of scientific and technical productivity. Economists have used patents as an output measure (Griliches 1984, Mansfield 1981, Mansfield 1986. Scherer 1965) while other researchers who have concentrated on the process of R\&D management have used publications as a surrogate measure of scientific output (Andrews 1979, Pelz \& Andrews 1976, Price 1980). We have examined here the interrelationship between these two output measures as well as some of the factors which may have significant influence on them.

Economic studies have often used research and development expenditures, and the number of $R \& D$ personnel as indicators of research inputs, and patents as the inventive output. One of the problems faced in using such measures is that the propensity to patent differs among industries. Even within a specific industry, firms often use patenting as a strategic tool. A senior executive in a high technology firm commented to us that its patent policy is geared to anticipating competentific papers) as the proxy for scientific output (Andrews 1979, Pelz \& Andrews 1976). Generally, these studies have focussed on the reasons for differences in productivity among individual scientists. Publications as well as citations to papers have been used as the proxy for quantity and quality of scientific output.

According to Carpenter el al. (1980), patents have generally been used in economic studies because they are easier to delineate than the more indirect benefits from a paper. Small and Greenlee (1977) have suggested that there may be a misconception that industrial scientists either do not publish or what they publish does not represent the important research of the firm. Due to this misconception, many studies have focussed on patents.

We have investigated the scientific and technical output of large industrial firms in the U.S. (publicly-held companies having annual sales of more than 250 million dollars) by examining both patents and publications. We examined the output trend for the past nine years and related this to such factors as sales, profits, R\&D expenditures, and the nature of the industry, as well as to the quality of the scientific staff.

\section{METHODOLOGY}

\section{Industry sample}

Our focus has been on 225 publicly-held companies which have a consistent history of substantial expenditure on research and development. More specifically, they spent either a minimum of $\$ 1$ million on R\&D between 1975 and 1983 or at least $1 \%$ of sales on R\&D between 1975 and 1983. Financial information such as sales, profits, and R\&D expenditure were obtained from Business Week magazine. We used Business Week data as well as its classification of the firms in various groups. Table 1 provides detailed information about these 225 companies categorized by different industry groups. 
Table 1 Intustry categories for sample firms

\begin{tabular}{lc}
\hline Industry category & No. of firms \\
\hline Aerospace & 8 \\
Appliances & 3 \\
Automobiles & 5 \\
Auto parts & 6 \\
Building materials & 8 \\
Chemicals & 25 \\
Conglomerates & 6 \\
Containers & 2 \\
Drugs & 20 \\
Electrical & 8 \\
Electronics & 13 \\
Food & 17 \\
Fuel & 10 \\
Information processing (computers) & 10 \\
Information processing (office equipmeni) & 6 \\
Instruments (control) & 11 \\
Leisure & 8 \\
Machinery & 12 \\
Metals and mining & 3 \\
Misc manufacturing & 8 \\
Oil service & 7 \\
Paper & 6 \\
Personal care & 8 \\
Semiconductor & 3 \\
Steel & 225 \\
Textiles & 3 \\
\hline Tire \& rubber & 7 \\
\hline & \\
\hline & 2 \\
\hline
\end{tabular}

For detailed discussion of the database searching techniques used, sec Halperin (1986).

Following Lawrence (1984), we further grouped these companies into four categories based on their production characteristics as follows:

1. High technology industries: companies requiring a high proportion of $R \& D$ or $\mathrm{em}-$ ploying scientists and engineers intensively; the following industries are included in this category:

aerospace, chemical, computer, drugs, electrical, electronics, instruments, leisure, office equipment, personal care, and semiconductor.

2. Resource intensive industries: companies requiring the intensive use of natural resources; the following industries are included in this category:

building materials, food, fuel, metals, oil service, and paper.

3. Capital intensive industries: companies using standardized production technologies and employing more capital than labour in production; the following industries are included in this category: appliances, automobiles, automobile parts, containers, machinery, rubber, steel, and textiles.

4. Other: Miscellaneous manufacturing and conglomerates were included in this category.
Table 2 Correlation coefficients publications and patents with firm characteristics

\begin{tabular}{lcc}
\hline Co. variable & No. of papers & No. of patents \\
\hline R\&D expenditure & .69 & .64 \\
Profit & .67 & .60 \\
Sales & .48 & .56 \\
Elite scientists & .74 & .79 \\
\hline
\end{tabular}

\section{SCIENTIFIC LITERATURE}

Data on scientific and technical papers were obtained from SCISEARCH , a machine readable multidisciplinary index to the literature of science and technology prepared by the Institute for Scientific Information ${ }^{\oplus}\left(\right.$ ISI $\left.^{\oplus}\right)$. All articles, reports of meetings, letters, editorials, correction notices from over 3,000 major scientific and technical journals are indexed in SCISEARCH.

\section{PATENT INFORMATION}

The number of patents granted to each of the 225 corporations for each year between 1975 and 1983 was obtained from BRS/PATSEARCH, an online database supplied by the BRS Company. This database contains all utility patents, reissue patents, and defensive publications issued by the U.S. Patent and Trademark Office since 1975. The 225 corporations in this study accounted for $17 \%$ of all U.S. patents issued for the period from 1975 to 1983 . When compared to patents issued to all U.S. corporations, these companies accounted for 38\% of patents issued in 1983 and $37 \%$ of those issued in 1975.

\section{ELITE SCIENTISTS}

To measure the quality of scientific and technical personnel in the 225 companies, we obtained data on numbers of elite scientists employed by each company. We used the Directory of American Men and Women of Science, Physical and Biological Sciences, as the source for our list of elite scientists. According to the Directory's introduction, inclusion in the work represents:

1. Achievement of stature in scientific work equivalent to that associated with the doctoral degree coupled with presently continued activity in such work.

2. Research activity of high quality in science.

3. Attainment of a position of substantial responsibility requiring scientific training and experience.

Using the on-line version of the Directory, we identified the elite scientists associated with the companies in this study. A total of 7,732 names of elite scientists were listed for the $225 \mathrm{com}$ panies.*

- American Men \& Women of Science, Physical and Biological Sciences Edited by Jaques Cattell Press: New York: Bowker 15th Edition 1982 
Table 3 Correlation coefficients publications and other factors controlting for size

\begin{tabular}{ll} 
Co. variable & $\begin{array}{c}\text { Correlation coeff } \\
\text { with No. of } \\
\text { papers/sales }\end{array}$ \\
\hline R\&D expenditure/sales & .47 \\
Profit/sales & .43 \\
Elite scientists/sales & .67 \\
Patents/sales & .39 \\
\hline
\end{tabular}

Table 4 Multiple regression result (papers/sales as the dependent variable)

\begin{tabular}{lcc}
\hline Variable & Adjusted $\mathbf{R}^{2}$ & $\mathbf{R}^{2}$ Change \\
\hline Scientists/sales & .45 & 45 \\
Percent patents & .54 & .09 \\
Patentsisales & .59 & 05 \\
R\&D/saies & .60 & .01
\end{tabular}

RESULTS

\section{Correlates of Publications \& Patents}

The correlation coefficient between patents and publications is 0.79 indicating a strong relationship between patenting and publication behaviours in these firms. Other factors such as sales, profit, R\&D expenditure, and, most important, numbers of elite scientists in the firm were all correlated with patents and publications as shown in Table 2.

The relationships between publications and these variables changed when we controlled for size of company by using sales as a measure of size. Table 3 provides these correlation coefficients.

Table 3 shows that the correlation coefficients are not only lower than the unadjusted correlations in Table 2, but also they have a different pattern. Number of elite scientists has the highest correlation and patent intensity is only weakly correlated with publication intensity.

\section{PUBLICATION INTENSITY: A REGRESSION ANALYSIS}

We used a stepwise multiple regression to examine further the relationship between publication intensity and company related variables. Publication intensity was used as dependent variable. The independent variables were patents as a percent of total of patents and papers, patents/sales, no. of elite scientists/sales, $R \& D$ expenditure/sales.

The regression equation is given as follows:

Papers $/$ sales $=25.6+.38$ (Elite scientists $/$ sales) -.40 (\% Patents) +.23 (Patents/sales) +.12 (R\&D/sales)

Table 4 provides the result of the multiple regression listing the variables and their contributions to explaining the variance of publication intensity.

The number of elite scientists per billion dollars of annual sales was the best single predictor of publication intensity. Alone it accounted for $45 \%$ of the variability in publication intensity. Patent intensity and $R \& D$ intensity were predictors of publication intensity. Patent intensity and R\&D intensity were predictors of publication intensity, but their power was much smaller. The percentage of patents was the only variable in the regression equation with a negative coefficient indicating a conflict between patent and publication policies.

\section{EFFECT OF INDUSTRY CHARACTERISTICS ON PUBLICATIONS}

Table 5 provides information on patents, publications, and elite scientists per company controlling for sales. From this table it is apparent that the high technology industry group leads in patenting and publishing as well as in the number of elite scientists employed per company. Compared with capital intensive industries, resource intensive industries have less patents but more papers and employ more elite scientists.

The relationships between patents, papers, and elite scientists for the different industry groups are presented in Table 6.

The large difference in correlation between the capital intensive and resource intensive industries may be the result of using sales to control for industry size. The resource intensive industry group (mainly oil production and oil service companies) had exceptionally high sales between 1975 and 1983. The capital intensive industry group (such as steel and automobiles) had depressed sales during the same period. This might have exaggerated

Table 5 Patents, publications, and elite scientists in different industries

\begin{tabular}{lcccc}
\hline $\begin{array}{l}\text { Industry } \\
\text { group }\end{array}$ & $\begin{array}{c}\text { No. of } \\
\text { Co. }\end{array}$ & $\begin{array}{c}\text { Patent } \\
\text { Co. }\end{array}$ & $\begin{array}{c}\text { Papers/ } \\
\text { Co. }\end{array}$ & $\begin{array}{c}\text { Elite Sc. } \\
\text { Co. }\end{array}$ \\
\hline High technology & 132 & 56.1 & 60.8 & 44.6 \\
Capital intensive & 28 & 40.9 & 16.1 & 16.1 \\
Resource intensive & 51 & 33.7 & 25.4 & 20.1 \\
Other & 14 & 45.7 & 23.8 & 26.8 \\
\hline
\end{tabular}


Table 6 Correlation between patents, publication, and elite scientists

\begin{tabular}{|c|c|c|c|}
\hline $\begin{array}{l}\text { Industry } \\
\text { group }\end{array}$ & $\begin{array}{c}\text { Patent/sales } \\
\& \\
\text { paper/sales } \\
\text { Pearson R }\end{array}$ & $\begin{array}{c}\text { Scientists/sales } \\
\& \\
\text { paper/sales } \\
\text { Pearson R }\end{array}$ & $\begin{array}{c}\text { Scientists/sales } \\
\& \\
\text { patents/sales } \\
\text { Pearson R }\end{array}$ \\
\hline High tech & .30 & .63 & .33 \\
\hline Capital intensive & .67 & .67 & .61 \\
\hline Resource intensive & .15 & .63 & .17 \\
\hline Other & .53 & .82 & .73 \\
\hline
\end{tabular}

the size of the resource intensive companies and underestimated the size of the capital intensive companies.

The strong relationship between elite scientists and publication intensity in all categories of the industry groups is contrasted with weaker relationship between scientists and patent intensity. It seems that although a scientist's reputation is certainly enhanced by the number of patents to his credit, patents represent the development stage of industrial production, while scientific publications are more often concerned with more prestigious basic research. Consequently, prestigious scientists working in industry would tend to seek employment with firms that gave them the opportunity to publish. Our explanation needs to be tested by further studies with in-depth interviews.

\section{FIRM SIZE AND PUBLICATION}

The relationship between inventive output and firm size has been studied by Scherer (1965). Based on the patents issued in 1959 to a sample of 352 firms from the list of the Fortune 500, he concluded that corporate patenting tends to increase less than proportionately with sales. We have examined the relationship between firm size and both patent and publication output of these 225 firms by using sales as the measure of size. Table 7 provides the data on sales, papers, and patents.

The pattern indicates that the publication of scientific papers increases less than proportionately to sales for the largest $\mathbf{1 0 0}$ firms. When this concentration measure is examined in detail, it shows that the publication of scientific papers increases more rapidly than sales past the 112th largest company. Put another way, the publication of papers increases less than proportionately for companies with average annual sales between 1975 and 1983 of more than 1.5 billion dollars. For companies with average annual sales of less than 1.5 billion dollars, the rate of publication exceeds the rate of sales. A similar pattern also emerges for patents, confirming Scherer's (1965) finding.

We examined the relationship between $R \& D$ productivity as measured by both the number of publications and number of patents per million of R\&D budget and firm size. Table 8 presents the data on $R \& D$ productivity for different sizes of firms.

From Table 8, we observe that R\&D productivity in terms of both paper publication and patents increases as firms decrease in size. The pattern is more consistent for production of patents than for paper publication per million R\&D dollars. Our finding is consistent with Soete (1978), who observed that the ratios of patents/R\&D and patents/sales for 126 U.S. companies were negatively related to the size of the firm.

\section{DISCUSSION AND CONCLUSIONS}

Both patents and publications are significant indicators of scientific output for industrial scientists in the U.S. As measured by the SCISEARCH database, the number of scientific publications for the 225 large public companies in this study in-

Table 7 Concentration measure of sales, papers, and patents

\begin{tabular}{|c|c|c|c|}
\hline $\begin{array}{l}\text { No. of firms } \\
\text { by sales }\end{array}$ & $\begin{array}{c}75-83 \\
\text { sales } \\
\end{array}$ & $\begin{array}{c}75-83 \\
\text { papers } \\
\%\end{array}$ & $\begin{array}{c}75-83 \\
\text { patents } \\
\text { क }\end{array}$ \\
\hline First 4 firms & 23.7 & 7.2 & 7.9 \\
\hline First 8 firms & 35.2 & 25.7 & 19.6 \\
\hline First 12 firms & 43.2 & 29.7 & 24.9 \\
\hline First 16 firms & 48.7 & 30.7 & 28.2 \\
\hline First 20 firms & 53.3 & 35.6 & 34.7 \\
\hline First 30 firms & 62.4 & 48.2 & 50.0 \\
\hline First 50 firms & 74.0 & 73.8 & 61.3 \\
\hline First 75 firms & 83.0 & 79.2 & 72.8 \\
\hline First 100 firms & 89.6 & 88.5 & 81.0 \\
\hline First 150 firms & 97.3 & 98.2 & 95.7 \\
\hline All 225 firms & 100 & 100 & 100 \\
\hline
\end{tabular}


Table 8 Firm size \& R\&D productivity

\begin{tabular}{lcc}
\hline $\begin{array}{l}\text { No. of firms } \\
\text { by sales }\end{array}$ & $\begin{array}{c}\text { No. of papers } \\
\text { /R\&D Smillion }\end{array}$ & $\begin{array}{c}\text { No. of patents } \\
\text { /R\&D Smillion }\end{array}$ \\
\hline First 4 firms & 0.211 & 0.235 \\
First 8 firms & 0.465 & 0.363 \\
First 12 firms & 0.460 & 0.396 \\
First 16 firms & 0.462 & 0.434 \\
First 20 firms & 0.467 & 0.456 \\
First 30 firms & 0.503 & 0.534 \\
First 50 firms & 0.531 & 0.542 \\
First 75 firms & 0.504 & 0.565 \\
First 100 firms & 0.524 & 0.574 \\
First 150 firms & 0.532 & 0.609 \\
All 225 firms & 0.526 & 0.618 \\
& & \\
\hline
\end{tabular}

creased $46.6 \%$ between 1975 and 1983. During the same period we observed a $23.4 \%$ decline in patents for these same companies. We must mention here that the measurement is confounded by the fact that the SCISEARCH database indexed 39.4\% more items in the same period.

Although we found that publications and patents are strongly correlated, this correlation became much weaker once we controlled for size. The lower correlation between patents/sales and paper/sales may be due to an inherent conflict between patenting and publication policies; a publication describing an invention may become a hindrance to obtaining a patent at a later date.

Publication intensity is most strongly correlated with the number of elite scientists/sales. As expected, it is also related to R\&D intensity and profitability of the firm.

Publication and patenting differ considerably among industry categories such as high technology, capital intensive and resource intensive, and others. On the average, firms in high technology industry have the highest number of patents, and papers and elite scientists. Firms in resource intensive industry, in comparison with those in capital intensive industry, have a lower number of patents but publish more papers and employ more elite scientists.

The strong correlations between papers/sales and elite scientists/sales for all four industry categories indicate that the number of elite scientists is a good predictor of publication behaviour. One can also argue that elite scientists will be attracted to firms where they can find opportunity to do more basic research and publish. The same conclusion does not hold for the correlation between patents/sales and elite scientists/sales.

Our study indicates that large firms are less efficient than smaller firms in both the publication of scientific papers and patenting. Our finding supports the conclusions drawn by both Scherer
(1965) and Soete (1978). R\&D productivity, measured in terms of patents/R\&D dollars, systematically increased with a decrease in firm size. Papers/R\&D dollars were higher for smaller firms, but the increase was not as regular as in the case of patents.

Our study was limited to publicly-held American companies with a nine year history of $R \& D$ expenditures in order to obtain information about them through secondary sources. This necessitated using firms with a minimum of 250 million dollars of annual sales, by no means small as per common use of the term. A further study of companies defined as small according to the Small Business Administration terminology may improve our understanding of the relationship between corporate size and inventive output.

\section{ACKNOWLEDGMENT}

Work in this area has been partially supported by a grant from the Division of Science Resources Studies, National Science Foundation, to the Center for Research on Technology \& Strategy, Drexel University Grant No. SRS 8509346. We thank two reviewers for their helpful comments.

REFERENCES

Andrews, F. M. (ed.) (1979), Sciensific Productivity: The Effecriveness of Research Groups in Six Countries, Cambridge: Cambridge University Press.

Carpenter. M. P. et al. (1980), 'Linkage between Basic Research Literature and Paten's', Research Managemont, March, 30-35. Griliches, Zvi (ed.) (1984), RAD, Patens, and Productivin, Chicago: University of Chicago Press.

Halperin, M. R. (1986), The Publication of U.S. Industrial Scientists: A Company and Industry Aralysis, PhD Dissertation, Drexel University.

Lawrence, R. Z. (1984), Can America Compete?, Washington, DC: Brookings Institution.

Mansfield, E. (1981), 'Composition of R\&D Expenditures: Relationship to Size of Firm. Concentration, and Innovative Output', Review of Economics and Statistics, 58, (4), November, 23-28.

Mansfield, E. (1986), 'Pateras and Innovation: An Empirical Study'. Management Science, 32, (2), February. 173-181.

Pelz, D. C. and Andrews, F. M. (1976), Scientists in Organizations: Productive Climate for Resewrch and Development, New York: Wiley.

Price, D. De Solla (1980), 'The Citation Cycle' in Belver C. Griffith (@d.), Key Papers in Information Sciesce, White Plains, New York: Knowledge Industry Publications, 195-210

Scherer, F. M. (1965). 'Firm Size, Market Structure, Opportunity, and the Output of Paterted Inventions'. American Economic Review, December, 55, (5), 1097-1125.

Small, H. and Greenlec, E. (1980), A Citation and Publication Analysis of U.S. Industrial Orgcnizations, National Science Foundation Contract PRM 77-10048.

Soete, L. L. G. (1978), Inventive Activity, Industrial Organization and International Trade, PhD Dissertation, University of Sussex, June. 